chemical examination of waters have been made, as well as investigations on bacteria in sea water and their rôle as denitrifiers. A two-hourly meteorological record was maintained, and the pilot balloon work was very successful. An interesting fact established is that the violent winds of certain parts of the Antaretic are mainly confined to the surface, seldom extending more than $500 \mathrm{ft}$. or $1000 \mathrm{ft}$. above groundlevel. Useful observations in magneties, solar radiation, and cosmic penetration have been made, while, of course, a rich harvest has been reaped in glaciology, geology, and ornithology.

The Discovery sailed from Melbourne about the middle of April and, if not delayed, may be expected in London shortly.

\section{A New Heat Engine.}

$A^{\mathrm{T}}$ the Royal Society of Arts on June 4, Mr. J. F. J. Malone, in a paper entitled "A New Prime Mover ", gave a description of a form of heat engine, invented by himself, in which the working medium is a liquid instead of a gas. In the course of his paper he stated that though mercury and oil have been tried, water has been found to be the most suitable medium, and in the engines to which reference was made only water has been used.

The main parts of the new form of engine consist of one or more working cylinders, a large number of long thick steel tubes in each of which is a movable displacer or regenerator, and a furnace. The tubes the author calls the thermodynamic tubes or 'T.D. tubes', and the regenerators, the thermodynamic piles or 'T.D. piles'. The tubes are closed at one end and at the other end are connected by pipes to the working cylinders. They are set in groups with their closed ends in the furnace, while the other ends are surrounded by water for cooling. The T.D. piles are built up of thin plates or tubes very closely spaced. The interior of the T.D. tubes, the very narrow spaces in the piles, the connecting pipes, and the working cylinders form a closed system completely full of water, which, when the engine is prepared ready for starting, is under an initial pressure of 1.4 tons per sq. in.

The engine depends for its action on the alternate expansion and contraction of the water in the system, due to the heating and cooling of the water in the T.D. tubes and piles, as the latter are moved to and fro in the tubes. For all practical purposes, the moving of the piles, which is done automatically by the engine, is equivalent to the alternate application and removal of the source of heat. Under these conditions the moving of the piles causes the pressure to rise to about 5.3 tons in one part of the stroke and then to fall to 1.4 tons per sq. in. Much ingenuity has been shown in the construction of the piles, which at first sight might appear likely to give trouble, but which have proved reliable on service.

Unfortunately, though the paper gave a few details of the several engines which have been built and run, these were by no means sufficient to form an estimate of the place the engine is likely to fill. One experimental engine was said to have run over $30,000,000$ revolutions, and on three brake tests by three different independent engineers an indicated efficiency of 27 per cent was obtained. It was also stated that allowing for furnace and mechanical losses, it was anticipated with a 100 h.p. engine an over-all efficiency of 20 per cent can be obtained, and this on a weight of about $330 \mathrm{lb}$. per indicated horse power. In the conclusion of his paper Mr. Malone claimed that the new engine possesses features which make it suitable both for locomotives and for ships.

\section{University and Educational Intelligence.}

Birmingham.--The degree of D.Sc. has been awarded to the following: Jonquei Su-Kwang Lee, for published work on "The Fusulinidæ of North China " (Palceontologia Sinica, series B, vol. 4), "Some Characteristic Structural Types in Eastern Asia and their Bearing upon the Problem of Continental Movement", "Geology of the Gorge District of the Yang-tse with special Reference to the Development of the Gorge ", and other papers ; Harry W. Webb. for published work on "Absorption of Nitrous Gases ", "Limitation of the Capacity of Platinum Catalyst" in Ammonia Oxidation ", and other papers.

Dr. A. Stanley Barnes has been appointed Dean of the Faculty of Medicine, in succession to Prof. Brash.

The following appointments have been made: Dr. R. H. Hoplsins, lecturer and head of the Department of Brewing in the Heriot-Watt College, Edinburgh, to the Adrian Brown chair of brewing; Mr. R. D. Lockhart, lecturer in anatomy, University of Aberdeen, to the chair of anatomy; Mr. P. Gray and Mr. D. Richards, to be resident staff tutor's for adult education under the Joint Committee of the Tniversity and the W.E.A.

Prof. A. M. Carr-Saunders has accepted an invitation to hold the Muirhead Lectureship for a further year.

CAMrridge.-The Harkness scholarship for proficiency in geology, of value $£ 117$, has been awarded to Miss F. E. S. Caldwell, of Newnham College.

The Frank Smart prizes have been awarded to P. W. Richards, of Trinity College, for botany, and P. Ullyett, of 'Trinity College, for zoology.

EDINBURGH. - At the graduation ceremony on July 2 the honorary degree of doctor of laws was conferred on the following, among others: Dr. E. J. Allen, Director of the Marine Biological Laboratory, Plymouth ; Sir George Andreas Berry, M.P. for the Scottish Universities, formerly lecturer in ophthalmo logy in the University of Edinburgh; and Sir Walter Morley Fletcher, secretary of the Medical Research Council.

The degree of doctor of science was conferred on Lucy Boyd, for a thesis on "Studies in the PostSeminal Development of the Monocotyledonous Embryo "; A. Cunningham, for a thesis on "Studies on Soil Micro-Organisms"; Esmé Mary Gilroy, for a thesis on "The Influence of Arginine upon Growth and Tissue Repair" ; Dr. M. Young, for a thesis on "A Contribution to the Study of the Growth of the Face in Childhood".

LEEDS.-At a graduation ceremony in connexion with the hundredth anniversary of the Leeds School of Medicine, the following honorary degrees were conferred, among others: Degree of doctor of lawsProf. A. G. Barrs, emeritus professor of medicine at Leeds and for more than fifty years connected with the School of Medicine; Sir John Bland-Sutton, consulting surgeon at the Middlesex Hospital ; Lord Dawson of Penn, president of the Royal College of Physicians; and Sir George Newman, Chief Medical Officer, Ministry of Health. Degree of doctor of science-Sir Walter Morley Fletcher, secretary of the Medical Research Council ; and Sir Frederiek Gowland Hopkins, president of the Royal Society

London.--The late Mr. J. F. H. Knight has bequeathed to the University a moiety of his residuary estate for the furtherance of teaching and research in the University. The bequest is expected to amount to about $£ 25,000$. 